Article

\title{
Identification of Diterpenoid Alkaloids from the Roots of Aconitum kusnezoffii Reihcb.
}

\author{
Ning Xu ${ }^{1}$, De-Feng Zhao ${ }^{1}$, Xin-Miao Liang ${ }^{2}$, Hua Zhang ${ }^{1, *}$ and Yuan-Sheng Xiao ${ }^{2, *}$ \\ 1 School of Chemical Engineering, Dalian University of Technology, Dalian 116000, China \\ 2 Key Lab of Separation Science for Analytical Chemistry, Dalian Institute of Chemical Physics, \\ Chinese Academy of Sciences, Dalian 116023, China \\ * Authors to whom correspondence should be addressed; E-Mails: zhanghua@dlut.edu.cn (H.Z.) or \\ xiaoys@dicp.ac.cn (Y.S.X.); Tel.: +86 041184379772 ; Fax: +086 041184379772.
}

Received: 22 February 2011; in revised form: 26 March 2011 / Accepted: 30 March 2011 /

Published: 19 April 2011

\begin{abstract}
Three diterpenoid alkaloids, including an unreported compound, were isolated from the roots of Aconitum kusnezoffii Reichb. On the basis of spectral analysis, these three compounds were determined to be 1,15-dimethoxy-3-hydroxy-14-benzoyl-16-ketoneoline, benzoylaconine and aconitine.
\end{abstract}

Keywords: roots of Aconitum kusnezoffii Reichb.; diterpenoid alkaloid; aconitum

\section{Introduction}

Aconitum kusnezoffii Reichb., belonging to the genus Aconitum L., is distributed in the Xinjiang, Sichuan and Jilin provinces of China. Although recently there were some reports on flowers [1] and leaves [2] of this plant, roots of Aconitum kusnezoffii Reichb. had been long used in Traditional Chinese Medicine as an analgesic and cardiotonic herbal medicine. Diterpenoid alkaloids [3,4] and polysaccharide [5] have been isolated from its roots to date. To our knowledge, diterpenoid alkaloids extracted from the genus Aconitum L. have various pharmacological properties [6-10]. In the search for biologically active alkaloids from the roots of Aconitum kusnezoffii Reichb., a detailed study was carried out. This led to the isolation of the new diterpenoid alkaloid 1,15-dimethoxy-3-hydroxy-14-benzoyl-16-ketoneoline, along with two known diterpenoid alkaloids, benzoylaconine and aconitine. Herein, the structure of the new compound was determined based on MS, 
IR, and NMR spectral data, and the known ones were identified by comparing their NMR data with those in the literature [3].

\section{Results and Discussion}

Compound 1 was obtained as a white solid. Its molecular formula was determined to be $\mathrm{C}_{32} \mathrm{H}_{43} \mathrm{O}_{9} \mathrm{~N}$ by ESI-MS (M/Z 586. $\left.861[\mathrm{M}+\mathrm{H}]^{+}\right)$. The ${ }^{1} \mathrm{H}-\mathrm{NMR}$ spectroscopic data of compound 1 showed three groups of absorptions for a benzoyl moity at $\delta_{\mathbf{H}} 7.47\left(2 \mathrm{H}, \mathrm{t}, \mathrm{H}-4^{\prime \prime}\right), 7.61\left(1 \mathrm{H}, \mathrm{t}, \mathrm{H}-5^{\prime \prime}\right)$, and $7.96(2 \mathrm{H}, \mathrm{d}$, $\left.\mathrm{H}-3^{\prime \prime}\right)$; N-ethyl protons at $\boldsymbol{\delta}_{\mathbf{H}} 2.72\left(1 \mathrm{H}, \mathrm{m}, \mathrm{H}-1^{\prime} \alpha\right), 2.74\left(1 \mathrm{H}, \mathrm{m}, \mathrm{H}-1^{\prime} \beta\right)$, and $1.14\left(3 \mathrm{H}, \mathrm{t}, \mathrm{H}-2^{\prime}\right)$; and four $O$-methyl protons at $\boldsymbol{\delta}_{\mathrm{H}} 3.28\left(3 \mathrm{H}, \mathrm{s}, \mathrm{CH}_{3} \mathrm{O}-1\right) 3.29\left(3 \mathrm{H}, \mathrm{s}, \mathrm{CH}_{3} \mathrm{O}-6\right), 3.30\left(3 \mathrm{H}, \mathrm{s}, \mathrm{CH}_{3} \mathrm{O}-18\right)$, and 3.82 $\left(3 \mathrm{H}, \mathrm{s}, \mathrm{CH}_{3} \mathrm{O}-15\right)$. The ${ }^{13} \mathrm{C}-\mathrm{NMR}$ and DEPT spectra of $\mathbf{1}$ revealed the presence of 32 carbons, which were assignable to a tertiary methyl group at $\boldsymbol{\delta}_{\mathrm{C}} 12.2(\mathrm{C}-2)$, an oxygenated methylene group at $\boldsymbol{\delta}_{\mathrm{C}} 76.3$ $(\mathrm{C}-18)$, an oxygenated quaternary carbon at $\boldsymbol{\delta}_{\mathrm{C}} 77.5(\mathrm{C}-8)$, two quaternary carbons at $\boldsymbol{\delta}_{\mathrm{C}} 43.6(\mathrm{C}-4)$ and $51.2(\mathrm{C}-11)$, four methylene groups at $\boldsymbol{\delta}_{\mathrm{C}} 31.8$ (C-12), $32.6(\mathrm{C}-2), 48.5\left(\mathrm{C}-1^{\prime}\right)$ and 49.3 (C-19), two carbonyl groups at $\boldsymbol{\delta}_{\mathrm{C}} 166.0\left(\mathrm{C}-1^{\prime \prime}\right)$ and $211.8(\mathrm{C}-16)$ and aromatic hydrocarbon signals at $\boldsymbol{\delta}_{\mathrm{C}} 128.7$ $\left(\mathrm{C}-4^{\prime \prime}\right), 129.1$ (C-2"), $129.7\left(\mathrm{C}-3^{\prime \prime}\right)$ and 133.8 (C-5'), respectively. After further analysis of the spectroscopic data, compound $\mathbf{1}$ was identified as a neoline-type diterpenoid alkaloid [11].

The $\mathrm{g}^{1} \mathrm{H}-{ }^{1} \mathrm{H}$ COSY, gHSQC and gHMBC spectra allowed the complete assignment of the chemical shifts of compound $\mathbf{1}$ (Table 1) [12-15].The ${ }^{1} \mathrm{H}-\mathrm{NMR}$ and ${ }^{13} \mathrm{C}-\mathrm{NMR}$ resonances of compound $\mathbf{1}$ were similar to those of chasmanine [3], which was also isolated from roots of Aconitum kusnezoffii Reichb., except for the different configurations of C-3, C-15, C-16 and C-14. The main differences are that the chemical shifts of C-3, C-15, C-16 and H-14 are $\boldsymbol{\delta}_{\mathrm{C}} 71.0,85.8,211.8$ and $\boldsymbol{\delta}_{\mathbf{H}} 5.44(\mathrm{~d}, J=5.0 \mathrm{~Hz})$ respectively in compound $\mathbf{1}$, and $\boldsymbol{\delta}_{\mathrm{C}} 35.0,38.7,81.9$ and $\boldsymbol{\delta}_{\mathbf{H}} 4.12(\mathrm{t}, J=4.5 \mathrm{~Hz})$ respectively in chasmanine, which suggested that $\mathrm{C}-3, \mathrm{C}-15$ and $\mathrm{C}-16$ in compound $\mathbf{1}$ belong to an oxygen-containing group. In the gHMBC spectrum, the correlations between $\mathrm{H}-18$ and $\mathrm{C}-3$, and between $\mathrm{H}-15$ and $\mathrm{CH}_{3} \mathrm{O}-15$ were important to confirm the presence of oxygen groups at $\mathrm{C}-3$ and $\mathrm{C}-15$. Further analysis of the ${ }^{13} \mathrm{C}$ NMR data suggested that $\mathrm{C}-16$ in compound $\mathbf{1}$ could be a carbonyl group, and not methoxyl group. The gHMBC correlations from $\mathrm{C}-1^{\prime \prime}$ to $\mathrm{H}-14$ and $\mathrm{H}-3$ " confirmed the position of a benzoyl group. In addition, it is noteworthy that the chemical shift of $\mathrm{H}-14$ in compound $\mathbf{1}$ was more deshielded than the same proton in chasmanine as the result of the steric effect of the carbonyl group at C-16. On the basis of the above spectral data, compound $\mathbf{1}$ was determined to be 1,15-dimethoxy-3-hydroxy-14-benzoyl-16-ketoneoline (Figure 1).

Figure 1. Structure and Key Correlations of Compound 1.

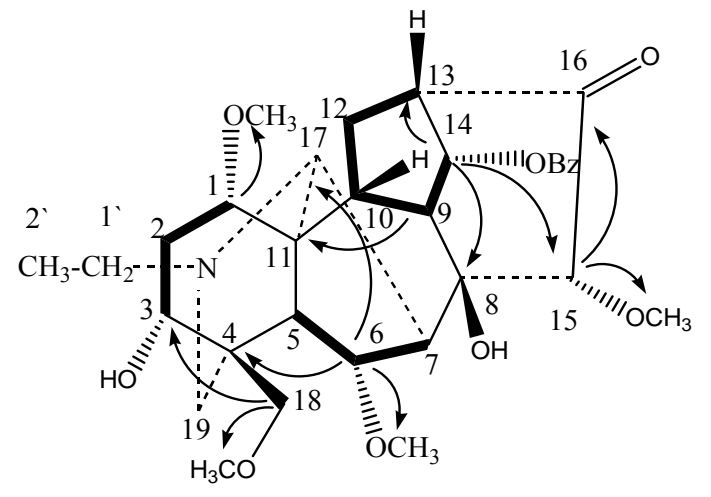

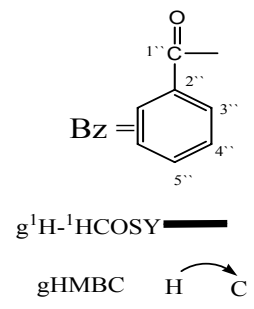


Table 1. 1D and 2D NMR Data for Compound 1 in $\mathrm{CDCl}_{3}$.

\begin{tabular}{|c|c|c|c|c|}
\hline & $\delta_{\mathrm{H}}$ & $\delta_{\mathrm{C}}$ & $\mathrm{g}^{1} \mathbf{H}_{-}{ }^{1} \mathrm{HCOSY}$ & gHSQC \\
\hline 1 & $3.20 \mathrm{~m}$ & 82.5 & $\mathrm{H}-2 \alpha, \mathrm{H}-2 \beta$ & + \\
\hline $2 \alpha$ & $1.97 \mathrm{~m}$ & 32.6 & $\mathrm{H}-1, \mathrm{H}-2 \beta, \mathrm{H}-3$ & + \\
\hline $2 \beta$ & $2.38 \mathrm{~m}$ & & H-1, H-2 $\alpha, H-3$ & + \\
\hline 3 & $3.88 \mathrm{~d} J=4.9 \mathrm{~Hz}$ & 71.0 & $\mathrm{H}-2 \alpha, \mathrm{H}-2 \beta$ & + \\
\hline 4 & - & 43.6 & - & - \\
\hline 5 & $2.23 \mathrm{~d} J=6.4 \mathrm{~Hz}$ & 46.5 & H-6, H-7, H-17 & + \\
\hline 6 & $3.95 \mathrm{~d} J=6.6 \mathrm{~Hz}$ & 83.7 & H-5, H-7, H-17 & + \\
\hline 7 & $2.79 \mathrm{~m}$ & 42.3 & H-6 & + \\
\hline 8 & - & 77.5 & - & - \\
\hline 9 & $2.84 \mathrm{~m}$ & 38.0 & $\mathrm{H}-10, \mathrm{H}-14$ & + \\
\hline 10 & $2.33 \mathrm{~m}$ & 44.2 & $\begin{array}{c}\mathrm{H}-9, \mathrm{H}-12 \alpha, \\
\mathrm{H}-12 \beta\end{array}$ & + \\
\hline 11 & - & 51.2 & - & - \\
\hline $12 \alpha$ & $1.92 \mathrm{~m}$ & 31.8 & $\begin{array}{c}\mathrm{H}-10, \\
\mathrm{H}-12 \beta, \mathrm{H}-13\end{array}$ & + \\
\hline $12 \beta$ & $2.91 \mathrm{dd} J=15.3 \mathrm{~Hz} J=6.9 \mathrm{~Hz}$ & & H-10, H- $12 \alpha$ & + \\
\hline 13 & $2.67 \mathrm{~m}$ & 49.4 & H-12 $\alpha$ & + \\
\hline 14 & $5.44 \mathrm{~d} J=5.0 \mathrm{~Hz}$ & 78.3 & H-9 & + \\
\hline 15 & $3.86 \mathrm{~s}$ & 85.8 & - & + \\
\hline 16 & - & 211.8 & - & - \\
\hline 17 & $3.15 \mathrm{~s}$ & 62.1 & H-5, H-6 & + \\
\hline $18 \alpha$ & $3.59 \mathrm{~d} J=8.7 \mathrm{~Hz}$ & 76.3 & $\mathrm{H}-18 \beta$ & + \\
\hline $18 \beta$ & $3.70 \mathrm{~d} J=8.7 \mathrm{~Hz}$ & & H- $18 \alpha$ & + \\
\hline $19 \alpha$ & $2.65 \mathrm{~d} J=11.9 \mathrm{~Hz}$ & 49.3 & $\mathrm{H}-19 \beta$ & + \\
\hline $19 \beta$ & $3.25 \mathrm{~d} \mathrm{~J}=11.9 \mathrm{~Hz}$ & & $H-19 \alpha$ & + \\
\hline $\mathrm{CH}_{3} \mathrm{O}-1$ & $3.28 \mathrm{~s}$ & 55.9 & - & + \\
\hline $\mathrm{CH}_{3} \mathrm{O}-6$ & $3.29 \mathrm{~s}$ & 58.3 & - & + \\
\hline $\mathrm{CH}_{3} \mathrm{O}-15$ & $3.82 \mathrm{~s}$ & 62.4 & - & + \\
\hline $\mathrm{CH}_{3} \mathrm{O}-18$ & $3.30 \mathrm{~s}$ & 59.2 & - & + \\
\hline $\begin{array}{c}\mathrm{N}-\mathrm{CH}_{2} \\
1^{\prime} \alpha\end{array}$ & $2.72 \mathrm{~m}$ & 48.5 & H-2' & + \\
\hline $1^{\prime} \beta$ & $2.74 \mathrm{~m}$ & & $\mathrm{H}-1 \alpha_{2} \cdot \mathrm{H}^{-} 2^{\prime}$ & + \\
\hline $\begin{array}{c}-\mathrm{CH}_{3} 2^{\prime} \\
\mathrm{Bz}\end{array}$ & $1.14 \mathrm{t} J=7.0 \mathrm{~Hz}$ & 12.2 & $\mathrm{H}-1^{\prime} \alpha, \mathrm{H}-1^{\prime} \beta$ & + \\
\hline $1^{\prime \prime}$ & - & 166.0 & - & - \\
\hline $2^{\prime \prime}$ & - & 129.1 & - & - \\
\hline $3^{\prime \prime}$ & $7.96 \mathrm{~d} J=7.6 \mathrm{~Hz}$ & 129.7 & $\mathrm{H}-4^{\prime \prime}$ & + \\
\hline $4^{\prime \prime}$ & $7.47 \mathrm{t} J=7.5 \mathrm{~Hz}$ & 128.7 & $\mathrm{H}-3^{\prime \prime}, \mathrm{H}-5^{\prime \prime}$ & + \\
\hline $5^{\prime \prime}$ & $7.61 \mathrm{t} J=7.1 \mathrm{~Hz}$ & 133.8 & $\mathrm{H}-4^{\prime \prime}$ & + \\
\hline
\end{tabular}




\section{Experimental}

\subsection{General}

IR spectra were recorded using a Thermo Nicolet Nexus spectrophotometer. 1D and 2D NMR spectra were obtained on Bruker AV400; $\boldsymbol{\delta}_{\mathbf{H}}$ values are expressed in parts per million relative to the solvent $\left(\mathrm{CDCl}_{3}\right)$ signal. DEPT, $\mathrm{g}^{1} \mathrm{H}-{ }^{1} \mathrm{H}$ COSY, gHSQC, and $\mathrm{gHMBC}$ experiments were carried out with the pulse sequences given by Bruker. LC-MS were performed on a UPLC instrument (Waters, USA) coupled with a ZQ 2000 mass spectrometer (Waters, USA) using an XTerra MS $\mathrm{C}_{18} 2.1 \times 150 \mathrm{~mm}$ column (Waters, USA) and a $\mathrm{C}_{18} \mathrm{HCE} 4.6 \times 150 \mathrm{~mm}$ column (self-made). A Waters Auto-Purification Factory was used in this study and consisted of a sample inJector (Waters 2777 sample manager), a passive splitter, a compensation pump (515 HPLC pump), an eight-channel UV detector (MUX-UV 2488), a four-channel MS detector (Micromass ZQ2000), four Waters 2525 binary gradient modules, and four Waters 2757 sample managers using XTerra MS $\mathrm{C}_{18} 19 \times 150 \mathrm{~mm}$ (Waters, USA) and $\mathrm{C}_{18} \mathrm{HCE}$ $10 \times 150 \mathrm{~mm}$ (self-made) columns. Data were collected using a MassLynx workstation.

\subsection{Plant Material}

Roots of Aconitum kusnezoffii Reichb. were collected in YiLi, Xinjiang Province, China, in July 2008. The herb was authenticated by Xi Rong He, Institute of Medication, Xiyuan Hospital of China Academy of Traditional Chinese Medicine. A voucher specimen (CAOWU 200807) was deposited at the School of Chemical Engineering, Dalian University of Technology.

\subsection{Extraction and Isolation}

Dried powdered roots of the plant $(50.0 \mathrm{~kg})$ were defatted with EtOH $(500.0 \mathrm{~L})$ over $12 \mathrm{~h}$. After removing the solvent under vacuum at $45{ }^{\circ} \mathrm{C}$, the residue was applied to $\mathrm{X}-4$ macroporous absorption resin and eluted with $\mathrm{H}_{2} \mathrm{O}$ followed in sequence by $30 \%, 50 \%$ and $100 \% \mathrm{EtOH}$ (v/v, aqueous-EtOH). The EtOH fractions were separated by column chromatography on silica gel eluted with petroleum, petroleum/EtOAc (v/v, 5:1), EtOAc and EtOH to obtain four fractions. Fraction 4 (15.0 g) was treated with a Waters Auto-Purification Factory using an XTerra $19 \times 150 \mathrm{~mm}$ column. The injection volume was $1.2 \mathrm{~mL}$. The flow rate was $17 \mathrm{~mL} / \mathrm{min}$. The mobile phases were $30 \mathrm{mM}$ ammonium acetate buffer $(\mathrm{pH}=8.0)$ and acetonitrile. Linear gradient elution was adopted starting from $10 \% \mathrm{Bp}$ to $90 \% \mathrm{Bp}$ : 0-40 min, 10-50\% Bp; 40-45 min, 50-90\% Bp and 45-60 min, 90-90\% Bp. Fraction 4 was separated to afford 40 fractions of $1.5 \mathrm{~min}$ each. Fractions 16-17 were separated by Pre-HPLC with formic $\mathrm{acid} /$ water $(0.2: 100, \mathrm{v} / \mathrm{v})$ and acetonitrile on $\mathrm{C}_{18} \mathrm{HCE} 10 \times 150 \mathrm{~mm}$. The injection volume was $1.0 \mathrm{~mL}$. The flow rate was $3 \mathrm{~mL} / \mathrm{min}$. Linear gradient elution was as follows: $0-10 \mathrm{~min}, 5-20 \% \mathrm{Bp} ; 10-30 \mathrm{~min}$, $20-25 \% \mathrm{Bp}$ and $30-50 \mathrm{~min}, 25-50 \% \mathrm{Bp}$. Fractions of $1 \mathrm{~min}$ each were collected. This separation yielded 1,15-dimethoxy-3-hydroxy-14-benzoyl-16-ketoneoline $(4.1 \mathrm{mg})$, benzoylaconine $(5.2 \mathrm{mg})$ and aconitine (3.2 mg). 


\subsection{Spectral Data}

1,15-Dimethoxy-3-hydroxy-14-benzoyl-16-ketoneoline: amorphous solid; IR (KBr) $v_{\max } 3480(\mathrm{OH})$, $2935(\mathrm{CH}), 1780$ (C=O, ester), 1451, 1382, 1320, 1282, 1180, 1,097, 983, $711 \mathrm{~cm}^{-1} ; \mathrm{UV} \lambda_{\max }\left(\mathrm{CAN} / \mathrm{H}_{2} \mathrm{O}\right)$ $232 \mathrm{~nm} ;{ }^{1} \mathrm{H}-$ and ${ }^{13} \mathrm{C}-\mathrm{NMR}$ data, Table 1; ESI-MS M/Z $\left.586.861[\mathrm{M}+\mathrm{H}]\right]^{+}$(calcd for $\mathrm{C}_{32} \mathrm{H}_{43} \mathrm{O}_{9} \mathrm{~N}, 585.041$ ).

\section{Conclusions}

Based on the results of our present study, roots of Aconitum kusnezoffii Reichb. contain diterpenoid alkaloids, which possess diverse biological properties, as the principal secondary metabolites. A new diterpenoid alkaloid, 1,15-dimethoxy-3-hydroxy-14-benzoyl-16-ketoneoline, together with two known alkaloids, benzoylaconine and aconitine, were separated from roots of Aconitum kusnezoffii Reichb., and their structures identified by spectral analysis.

\section{Supplementary Materials}

Supplementary materials can be accessed at http:/www.mdpi.com/1420-3049/16/4/3345/s1.

\section{Acknowledgements}

We thank the Key lab of Separation Science for Analytical Chemistry, Dalian Institute of Chemical Physics, Chinese Academy of Sciences for support.

\section{References and Notes}

1. Wang, Y.; Song, F.R.; Xu, Q.X.; Liu, Z.Q.; Liu, S.Y. Characterization of aconitine-type alkaloids in the flowers of Aconitum kusnezoffii by slectrospray ionization tandem mass spectrometry. Acta Pharm. Sin. 2003, 38, 962-970.

2. Yu, H.L.; Jia, S.S. A norterpenoids alkaloid, Beiwucine from the leaves of Aconitum kusnezoffii Reichb as Mongolia Medicine. Acta Pharm. Sin. 2000, 35, 232-234.

3. Li, Z.B.; Lu, G.H.; Chen, D.L.; Wang, F.P. Chemical study on the alkaloids of "CAO WU". Nat. Prod. Res. Dev. 1997, 9, 9-14.

4. Zinurova, E.G.; Khakimova, T.V.; Spirikhin, L.V.; Yunusov, M.S.; Gorovoi, P.G.; Tolstikov, G.A. A new norditerpenoid alkaloid acsonine from the roots of Aconitum Kusnezoffii Reichb. Russ. Chem. Bull. 2001, 50, 311-312.

5. Sun, Y.J.; Chen, Y.; Wu, J.J.; Wang, B.S.; Guo, Z.R. Studies on the isolation, purification and composition of Acontium kusnezoffii polysaccharide. Chin. Pharm. J. 2000, 35, 731-733.

6. Heubach, J.; Schüle, A. Cardiac effects of Lappaconitine and $N$-Deacetyltappaconitine, Two diterpenoid alkaloids from plants of the Aconitum and Delphinium species. Planta Med. 1998, 64, 22-26.

7. Saito, H.; Ueyama, T.; NaKa, N.; Yagi, J.; Okamoto, T. Pharmacological studies of Lgnavine, an aconitum alkaloid. Chem. Pharm. Bull. 1982, 30, 1844-1850.

8. Wang, J.; Heiden, R.; Spijksma, G.; Reijmers, T.; Wang, M.; Xu, G.; Hankemeier, T.; Greef, J.; Murayama, M.; Mori, T.; Bando, H.; Amiya, T. Studies on the constituents of aconitum species. IX. 
The pharmacological properties of pyro-type Aconitine alkaloids, components of processed aconite powder 'kako-bushi-matsu': analgesic, antiinflammatory and acute toxic activities. $J$. Ethnopharmacol. 1991, 35, 159-164.

9. Ameri, A. The effects of Aconitum alkaoids on the central nervous system. Prog. Neurobiol. 1998, 56, 211-235.

10. Zhao, X.Y.; Wang, Y.; Li, Y.; Chen, X.Q.; Yang, H.H.; Yue, J.M.; Hu, G.Y. Songorin, a diterpenoid alkaloid of the genus Aconitum, is a novel $\mathrm{GABA}_{\mathrm{A}}$ receptor antagonist in rat brain. Neurosci. Lett. 2003, 337, 33-36.

11. Hanuma, J.B.; Katz, A. 1H-NMR spectra of norditerpenoid Alkaloids. A Review. J. Nat. Prod. 1994, 57, 1473-1483.

12. Pelletier, S.W.; Chokshi, H.P.; Desai, H.K. Separation of diterpenoid alkaloid mixtures using vacuum liquid chromatography. J. Nat. Prod. 1986, 49, 892-900.

13. Liu, H.M.; Katz, A. Diterpenoid alkaloids from Aphids Brachycaudus aconiti and Brachycaudus napelli feeding on Aconitum napellus. J. Nat. Prod. 1996, 59, 135-138.

14. Arlandini, E.; Ballabio, M.; Gioia, B.; Colombo. M.L.; Tomé, F. N-Deethylaconitine from Aconitum napellus ssp. Vulgare. J. Nat. Prod. 1987, 50, 937-939.

15. Joshi, B.S.; Srivastava, S.K.; Barber, A.D.; Desai, H.K.; Pelletier, S.W. Selective demethylation of some Aconitine-Type norditerpenoid alkaloids. J. Nat. Prod. 1997, 60, 439-443.

Sample Availability: Samples of the compounds are available from the authors.

(C) 2011 by the authors; licensee MDPI, Basel, Switzerland. This article is an open access article distributed under the terms and conditions of the Creative Commons Attribution license (http://creativecommons.org/licenses/by/3.0/). 